INTERNATIONAL

CENTER FOR

PUBLIC POLICY
International Center for Public Policy

Working Paper 20-10

June 2020

Implementing Federalism: The Case of Nepal

Roy W. Bahl

Andrey Timofeev

Serdar Yilmaz

GeorgaState University 



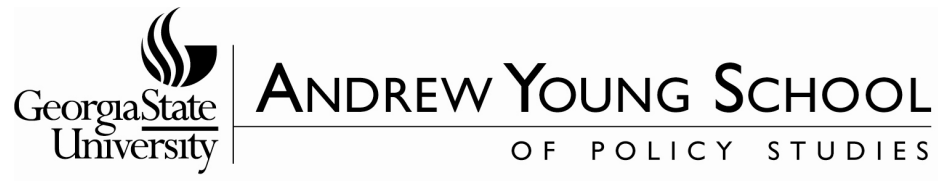

International Center for Public Policy

Working Paper 20-10

\section{Implementing Federalism: The Case of Nepal}

\author{
Roy W. Bahl \\ Andrey Timofeev \\ Serdar Yilmaz
}

June

2020

International Center for Public Policy

Andrew Young School of Policy Studies

Georgia State University

Atlanta, Georgia 30303

United States of America

Phone: (404) 413-0235

Fax: (404) 651-4449

Email: paulbenson@gsu.edu

Website: http://icepp.gsu.edu/

Copyright 2020, the Andrew Young School of Policy Studies, Georgia State University. No part of the material protected by this copyright notice may be reproduced or utilized in any form or by any means without prior written permission from the copyright owner. 


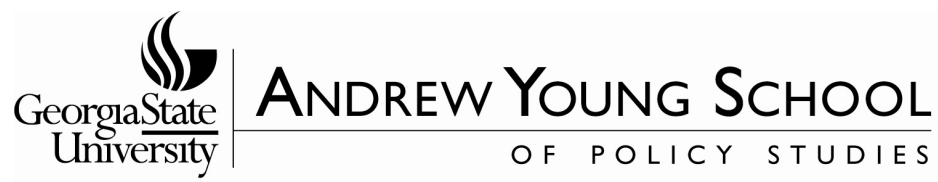

\section{International Center for Public Policy Andrew Young School of Policy Studies}

The Andrew Young School of Policy Studies was established at Georgia State University with the objective of promoting excellence in the design, implementation, and evaluation of public policy. In addition to four academic departments, including economics and public administration, the Andrew Young School houses eight leading research centers and policy programs, including the International Center for Public Policy.

The mission of the International Center for Public Policy (ICePP) at the Andrew Young School of Policy Studies is to provide academic and professional training, applied research, and technical assistance in support of sound public policy and sustainable economic growth in developing and transitional economies.

ICePP is recognized worldwide for its efforts in support of economic and public policy reforms through technical assistance and training around the world. This reputation has been built serving a diverse client base, including the World Bank, the U.S. Agency for International Development (USAID), the United Nations Development Programme (UNDP), finance ministries, government organizations, legislative bodies, and private sector institutions.

The success of ICePP reflects the breadth and depth of its in-house technical expertise. The Andrew Young School's faculty are leading experts in economics and public policy and have authored books, published in major academic and technical journals, and have extensive experience in designing and implementing technical assistance and training programs. Andrew Young School faculty have been active in policy reform in over 40 countries around the world. Our technical assistance strategy is not merely to provide technical prescriptions for policy reform, but to engage in a collaborative effort with host governments and donor agencies to identify and analyze the issues at hand, arrive at policy solutions, and implement reforms.

ICePP specializes in four broad policy areas:

- Fiscal policy (e.g., tax reforms, public expenditure reviews)

- Fiscal decentralization (e.g., reform, intergovernmental transfer systems, urban finance)

- Budgeting and fiscal management (e.g., local, performance-based, capital, and multiyear budgeting)

- Economic analysis and revenue forecasting (e.g., micro-simulation, time series forecasting)

For more information about our technical assistance activities and training programs, please visit our website at icepp.gsu.edu or contact us at paulbenson@gsu.edu. 


\title{
Implementing Federalism: The Case of Nepal
}

\author{
Roy W. Bahl, Andrey Timofeev, and Serdar Yilmaz
}

June 2020

\begin{abstract}
The new constitution of Nepal established a federal system of governance in 2015. Local elections were held in 2017 and implementation began in 2018. The new system is composed of seven provinces and 753 local governments structured in a decentralized form of fiscal federalism. The Constitution assigns important functional responsibilities to provincial and local governments, and mandates that they have significant autonomy in deciding how services will be delivered. Subnational governments will account for about one-third of (budgeted) total government expenditures in FY 2019, financed primarily by intergovernmental transfers. This paper describes the new federal system (now in its third year of operation), discusses the early implementation successes and challenges, and draws some lessons from Nepal's experience.
\end{abstract}

${ }^{1}$ Bahl: rbahl@gsu.edu | International Center for Public Policy, Andrew Young School of Policy Studies, Georgia State University; Timofeev: atimofeev@gsu.edu | International Center for Public Policy, Andrew Young School of Policy Studies, Georgia State University; Yilmaz: The World Bank 


\section{Introduction}

In 2015, the new constitution of Nepal established a federal system of governance. The new system would be composed of seven provinces and 753 local governments structured in a decentralized form of fiscal federalism. ${ }^{1}$ It was, by any stretch of the imagination, a "big bang" reform. The pre-constitution governance structure had no provincial governments. There were over 3,000 local government units with little autonomy, and the central government had little or no experience in managing a decentralized intergovernmental system. Local elections had not been carried out in almost two decades. ${ }^{2}$

This paper describes the new federal system, (now in its third year of operation), discusses the early implementation successes and challenges, and draws some lessons from Nepal's experience. The next section briefly reviews the background and history that brought Nepal to this dramatic change in governance. Then we turn to a description and analysis of the features of Nepal's new fiscal federalism and to the capacity of subnational governments to absorb this new system of financing and expenditure delivery in such a short period of time. A final section discusses some of the main barriers to implementation of the new federalism. The paper

\footnotetext{
${ }^{1}$ While the seven provinces were established by the 2015 Constitution. The establishment of local governments was left to the Local Level Restructuring Commission (LLRC), subsequently formed on March 15, 2016, with a mandate to propose new local units within a year. On January 6, 2017, the LLRC initially proposed 719 local units, which was increased to 753 units in response to protests from Madhesh-based parties and intervention of the Supreme Court (Democracy Resource Center Nepal, 2018).

${ }^{2}$ The restoration of multiparty democracy in the 1991 Constitution gave impetus to strengthening local selfgovernments. Implementation of the constitutional promise of popular participation through decentralization allowed for local democratic elections to take place in 1992. Subsequently, the adoption of the Local Self Governance Act (LGSA) of 1999 increased hopes for consolidation of local governance system and implementation of decentralization policies. The gradual implementation of the LSGA provisions was never completed due to the Maoist insurgency that started in 1996. Furthermore, the conflict disrupted local elections and led to the absence of elected local authorities after 2002. After the adoption of the 2015 Constitution, the first phase of the local elections was held on May 14, 2017, in 34 districts of Nepal. Following this, local elections were carried out in most of the remaining local and provincial government jurisdictions on June 28, 2017, while the elections in province no. 2 were postponed to September 18, 2017. With the parliament dissolved on October 13, 2017, the general and provincial elections were held on November 26, 2017 (32 districts) and December 7, 2017 (45 districts).
} 
concludes with some questions about the lessons that other countries might draw from Nepal's experience with putting a federal system in place.

\section{Background}

Nepal has long attempted to establish some form of local self-government but has had relatively little success (Pokharel 2009 and Kelly 2016). The previous Constitution allowed for local democratic elections to take place in 1992. The Local Self Governance Act (LSGA) of 1999 established 3,915 Village Development Committees (VDC), 58 Municipalities, and 75 District Development Committee (DDC). The chief officers of these local bodies were central government employees, and staff was seconded from the central government. The gradual implementation of the LSGA provisions for more local autonomy was never completed due to the Maoist insurgency that started in 1996. The conflict disrupted local elections and led to the absence of elected local authorities after 2002.

The Constitution of 2015, stemming from the Comprehensive Peace Agreement of 2006, designed the new federal structure with the primary goal of nation building. It moved forward with subnational elections, established provincial and local governments with significant fiscal autonomy, and put in place a new system that would transfer responsibility for spending an amount equivalent to about one-third of total government expenditures to subnational governments. Though the costs of transitioning to the federal system will be significant, the shift to a federal structure might produce long-term benefits that outweigh these costs:

- The avoidance of conflict would be a major benefit. One study reported that the civil war in Nepal was responsible for a cost equivalent to about 3 percent of GDP (Ra and Singh, 
2005). ${ }^{3}$ Such measures of the cost of conflict are important to consider, even if accurate measurement is not possible.

- Increased productivity of the disadvantaged population that results from more education of minorities and women ("disadvantaged population"), more job opportunities for the disadvantaged, more public services directed to their needs and less discrimination can increase the stock of wealth in a country. A World Bank study estimates that gender equality alone would be consistent with a 14 percent increase in the worldwide wealth of nations (Wodon and de la Briere, 2018).

More voice in government decisions about services provided could result in local populations getting more of the services they want from government. This suggests more accountability of public officials, and a greater willingness by local populations to pay taxes and charges.

Nepal has pushed the implementation of its new federal system and has accomplished much. Many of the necessary framework laws are in place, ${ }^{4}$ an interim intergovernmental transfer system is being used, ${ }^{5}$ basic expenditure assignments have been made, and the devolution of staff to the provincial and local government levels is underway. Local government elections were successful, officers are in place, and provincial and local governments are functioning. Assemblies are meeting regularly, laws and regulations are being developed, budgets were passed, most financials have been audited, and in the first year of implementation, there was a feeling in the general population that things are moving in the right direction (NASC, 2018). But provincial and local governments are still at a very early stage of learning to manage and deliver

\footnotetext{
${ }^{3}$ This estimate is similar to the results obtained from international comparative analysis in other conflict countries (Collier, 1997).

${ }^{4}$ Key pieces of legislation enacted include: (i) the Local Government Operations Act, 2074 (2017); (ii) the Intergovernmental Finance Management Act, 2074 (2017); (iii) the National Natural Resource and Fiscal Commission Act, 2074 (2017); (iv) Employee Adjustment Act, 2074 (2017) subsequently replaced with the Civil Servant Adjustment Act, 2075 (2019) ; and (v) Province Public Service Commission (Bases and Criteria Determination) Act, 2075 (2019 The latter has paved the way for the provincial governments to prepare their legislations to establish PPSCs within the framework given by the federal law.

${ }^{5}$ The Intergovernmental Finance Management Act, 2074 provides further clarity to the Constitutionally mandated four types of transfers: fiscal equalization grants, conditional grants, complementary (matching) grants, and special grants.
} 
public services, and they are undercapitalized in terms of both human and physical capital (GSU, 2019).

\section{Nepal's New Governance and Fiscal Federalism}

The provincial and local governments in Nepal have taken on broad powers in law making, budget formulation, planning and policy formulation, and implementation, and will take on the responsibility for delivering most local public services. The federal government will be responsible for provision of public goods that have primarily national benefits, but its focus will shift toward macro policy making, management, monitoring of the new intergovernmental fiscal system, and setting and enforcing standards.

The Constitution features a federal structure of government, but not the hierarchical arrangement that is the case in many other federations. It calls on federal, provincial, and local governments to enjoy relations “...based on principles of cooperative, coexistence and coordination” (Art. 232). This suggests the objective of strong local (third tier) government autonomy with little direct control by the federal or provincial governments, though there are provisions for centralization to address matters of national importance and coordination.

Our estimates suggest that sub-national governments will account for 34 percent of (budgeted) total government expenditures in FY $2019 .{ }^{6}$ This is well above the international average of about 20 percent for low- and middle-income countries (Bahl and Bird, 2018, p.46). On the revenue side, the system remains highly centralized with a relatively small contribution from sub-national

\footnotetext{
${ }^{6}$ We calculate this percentage as the total intergovernmental transfers (including shared taxes and locally raised revenues) as the numerator and total government expenditures inclusive of intergovernmental transfers as the denominator. Data are taken from the budget estimates for FY 2019, revised estimates for FY 2018, and the Minister's budget speech (2018).
} 
government taxes that is mostly centered in urban areas. About 53 percent of budgeted federal government tax collections is assigned to intergovernmental transfers. ${ }^{7}$

\section{Expenditure Assignments}

The distribution of expenditure responsibilities among the three levels of government is more or less consistent with international norms, i.e., functions with national benefits are assigned to the federal level, those with regional benefit zones to the provincial level, and those where benefits accrue roughly to local government boundaries to third tier local governments. Consistent with the goal of local self-government, the third-tier local governments received responsibility for most basic functions, including primary and secondary education, health and sanitation services, local roads, irrigation and the management of local markets. This decentralization has come with significant autonomy at the subnational level to decide how services will be delivered, and how they will be paid for. ${ }^{8}$

\section{Revenue Assignments}

As is the case in most low- and middle-income countries, few productive tax bases are assigned to subnational governments. The value added tax, excises and customs duties and income taxes are reserved by the Constitution (schedule 5) for the federal government. Provincial governments can impose land and building registration fees, vehicle, advertisement, tourism and entertainment

\footnotetext{
${ }^{7}$ Tax sharing (70 percent of revenues collected from excise taxes and VAT on domestic goods) is included in this computation as an intergovernmental transfer.

${ }^{8}$ The creation of 760 autonomous provincial and local governments creates a strong potential for a culture of accountability to voters. Four features that Nepal has embraced in its new system to strengthen the accountability of public officials to voters are (a) elections, (b) the assignment of important expenditure responsibilities to subnational governments, (c) citizen participation, and (d) transparency. Imperfect as the process is, open elections are probably the best available way to make subnational government officials accountable to the local population. Presumably, local officials will be re-elected depending partly on the package of services provided and the tax price charged. However, there is an apparent concern that a great number of Nepal's voters are not well versed on their rights to hold decision-makers accountable (Democracy Resource Center, 2017; NASC, 2018).
} 
taxes, agricultural income taxes and various fees and service charges (schedule 6). Local governments are assigned various forms of property and rent taxes, registration fee for land and houses, vehicle registration fee, and some other minor taxes and charges (schedule 8). The result of these assignments is a significant vertical imbalance that subnational governments must cover with intergovernmental transfers allocated from the federal government.

\section{Intergovernmental Transfers}

Besides assigning specific revenue sources to subnational levels, the Constitution (art. 60) also envisioned that the federal government would "equitably distribute the revenue generated by it from its sources, between the federation, province and the local level entities." The Constitution also distinguished between four specific transfer channels: 1) equalization grants; 2) conditional grants; 3) complementary (matching) grants and 4) special grants. The constitution further specified criteria for transfer allocation in general and equalization grants in particular (expenditure needs, revenue capacity and effort).

The Intergovernmental Finance Management Act (IFMA) of 2074 (2017) mandates placing the revenues collected from excise taxes and VAT on domestic goods first in a federal divisible pool to be subsequently allocated as follows: 70 percent to the Federal Consolidated Fund, 15 percent to the provincial divisible pool, and 15 percent to the local divisible pool. The provincial and local divisible pools are to be distributed among recipient governments by formula. ${ }^{9}$ In effect, this can be viewed as an entitlement where sub-national governments have a specified claim against central tax collections. IFMA introduces similar arrangements for sharing of royalties

\footnotetext{
${ }^{9}$ This tax sharing entitlement was allocated for the first time in FY 2018/2019. As used in Nepal, it is a direct claim against national tax collections rather than a transfer from the consolidated fund. It is not explicitly provided for in the Constitution. Note also that because of this feature, the national budget does not classify the tax sharing grant as an intergovernmental transfer to subnational governments.
} 
and natural resource revenues with the exception that the horizontal allocation formulas only apply to those municipalities where these revenues are generated.

Furthermore, the IFMA (art. 18(2)) implies that the allocation of the provincial and local divisible pools is to be done through a grant channel separate from the four channels specifically mentioned in the constitution (equalization grants; conditional grants; complementary (matching); and special grants). Thus, the IFMA empowers the (independent) National Natural Resource and Fiscal Commission (NNRFC) to recommend the Parliament vote on the amounts of the four grant pools on top of the provincial and local divisible pools fixed in the law. The total vertical shares in Nepal (tax sharing and four other grant channels) were 7.97 percent of GDP in 2018 and budgeted to reach 12.9 percent in 2019 (the first two years of federalism) with about 60 percent of the total amount designated for the 753 local level governments in 2019 (Table 1).

Table 1. Intergovernmental Transfers: Vertical Shares

\begin{tabular}{|c|c|c|c|c|}
\hline . & 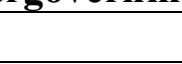 & Amount (in NPR mn) ${ }^{\mathrm{a}}$ & Percent Distribution & Percent of GDP \\
\hline \multirow{3}{*}{2018} & Local & 234,466 & 97.04 & 7.74 \\
\hline & Provincial & 7,146 & 2.96 & 0.24 \\
\hline & Total & 249,968 & 100 & 7.97 \\
\hline \multirow{3}{*}{$\begin{array}{c}2019 \\
\text { (budget) }\end{array}$} & Local & 262,173 & 59.2 & 7.6 \\
\hline & Provincial & 180,554 & 40.8 & 5.3 \\
\hline & Total & 442,727 & 100 & 12.9 \\
\hline
\end{tabular}

Source: Government of Nepal data; Budget Speech FY 2018/2019

The horizontal share of an intergovernmental transfer is the distribution of the divisible pool among the individual local and provincial governments. In Nepal, these distribution arrangements vary by grant program. Tax sharing and equalization grants are distributed by two different formulae, but both are based on indicators of expenditure needs and both are unconditional transfers. Equalization grants target the disparity between expenditure needs and 
revenue potential, and the VAT/Excise tax sharing grants target fiscal imbalance more generally. ${ }^{10}$ The formulae were developed by the NNRFC secretariat and are under regular review as part of the continuing efforts to assess expenditure needs and revenue potential of subnational governments.

Conditional grants, on the other hand, are presently payments to sub-national governments to implement (newly devolved) federal programs according to national standards and to comply with national and international commitments. Some of these conditional grants are more in the nature of cost reimbursement grants because they are used to guarantee the cost of salaries of transferred central government employees (mostly education and health) and to cover the costs of legacy projects from the former centralized regime. Less important in the present system are special and matching grants that are distributed to defray part of the cost of local implementation of special projects of the federal government.

Transfers in the 2019 budget were planned for about 30 percent for equalization grants, and about 26 percent for tax sharing grants, both of which are distributed without conditions attached as to how the money must be spent. Conditional grants take up about 39 percent of total grant funding (Table 2). There also is provision in the constitution for provincial government grants to local governments.

\footnotetext{
${ }^{10}$ Note that the equalization formula for 2019 weighted the gap between expenditure needs and revenue capacity more heavily than in the previous year, suggesting that the bias in favor of smaller local governments might be lessened.
} 
Table 2: Intergovernmental Transfers, 2018 and 2019, by Percent Distribution

\begin{tabular}{|c|c|c|c|}
\hline & Description & FY 2018 & FY 2019 (budget) $^{\mathrm{a}}$ \\
\hline \multirow{6}{*}{$\begin{array}{c}\text { Local } \\
\text { Governments }\end{array}$} & Equalization Grants & $63.4 \%$ & 32.5 \\
\hline & Conditional grants & $36.6 \%$ & 41.9 \\
\hline & Complementary Grants & & 1.9 \\
\hline & Special Grants & & 1.9 \\
\hline & Tax Sharing Grants & & 21.8 \\
\hline & Total & 100 & 100 \\
\hline \multirow{6}{*}{$\begin{array}{c}\text { Provincial } \\
\text { Governments }\end{array}$} & Equalization grants & 100 & 27.9 \\
\hline & Conditional grants & & 35.0 \\
\hline & Complementary grants & & 2.8 \\
\hline & Special Grants & & 2.8 \\
\hline & Tax Sharing grants & & 31.6 \\
\hline & Total & 100 & 100 \\
\hline \multirow{6}{*}{$\begin{array}{c}\text { All } \\
\text { Governments }\end{array}$} & Equalization grants & $64.5 \%$ & 30.6 \\
\hline & Conditional grants & $35.5 \%$ & 39.1 \\
\hline & Complementary grants & & 2.3 \\
\hline & Special grants & & 2.3 \\
\hline & Tax Sharing Grants & & 25.8 \\
\hline & Total & 100 & 100 \\
\hline \multicolumn{2}{|c|}{ Exhibit: Total Grants to PLG as a Percent of GDP } & 10.9 & 12.9 \\
\hline
\end{tabular}

Source: Government of Nepal, Budget Speech FY 2018/2019

\section{Barriers to Implementing the New Federalism}

Much has been accomplished since the new Constitution became effective in 2105 , but there is much still to be done. Important national framework legislation has not yet come online, in part because the governance reform shift in Nepal has resulted in complicated political economy considerations requiring time-consuming navigation, and because a strong "champion" for pushing the devolution agenda is yet to emerge. Implementation at the local level has also posed a challenge. There was a general push to get going with local self-governance even though elected provincial and local government officials, and many voters, were not yet familiar with their new powers and responsibilities. Finally, the transition to federalism has been constrained 
because it went forward without the benefit of a comprehensive implementation plan or a timetable for sequencing the introduction of new policies.

\section{Devolution of Government Employment}

The Constitution assigns important functional responsibilities to provincial and local governments, and mandates that they have significant autonomy in deciding how services will be delivered. Furthermore, the transitional clauses of the Constitution (art 302(2)) called for integration of the "personnel working in government services at the time of commencement of this constitution into the provincial and local level." The Government of Nepal used this clause as justification to bar subnational governments from recruiting their own staff until the federal government determines which of the existing civil servants are still needed at the federal level in light of the constitutional division of functions, while transferring the rest to subnational levels. The Ministry of Federal Affairs and Government Administration (MOFAGA) carried out analyses to guide the number of employees to be put in place at each level of government and worked out a plan for individual assignments.

This civil service adjustment program, completed in 2019, did not result in completely filling the capacity-needs gap of sub-national governments. Neither is it likely to provide enough initial management capacity, with the right skills, to meet the needs of provincial and local governments, especially in technical areas such as engineering and accounting. Until these employment gaps are filled, the promised improvement in public services is unlikely to materialize. 
Providing a Legal Framework for Federalism

For Nepal's federalism to be implemented successfully, a significant amount of framework legislation is required. This includes laws to assign expenditure, revenue, and public management responsibilities among the three spheres of government and to enable the issuance of necessary laws at the provincial and local government level. Much of this has been done, but the time it has taken to pass or amend some national framework and operations legislation has contributed to a lack of clarity in the division of responsibilities and powers of the different levels of government, uncertainties about operating procedures, and an inability of local and provincial governments to deliver on all of their new responsibilities. The Civil Servant Adjustment Act and Province Public Service Commission (Bases and Criteria Determination) Act were passed in February 2019 but other enabling legislation for provincial public service commissions has not been enacted. The passage of provincial and local laws is also a challenge because the legal training and background of staff at the sub-national government level is limited.

\section{Institutional and Organizational Arrangements}

The Constitution calls for the empowerment of several institutions that are particularly important to moving the implementation of federalism forward.

Public service commissions are to be formed in each province. The powers of the provincial commissions will be set by provincial law, within the framework set by the recently enacted federal framework law. But the impasse with the Federal Civil Service Bill holds up adoption of 
other federal framework legislation that will guide each provincial commission in recruiting and hiring. $^{11}$

An Inter-Provincial Council (IPC) is provided for in the Constitution to settle disputes of a political nature between the federation and province, and among the provinces. The membership includes the Prime Minister, the Ministers of Home Affairs and Finance, and the Chief Ministers of the Provinces. The inputs of the Inter-Provincial Council in planning for the remainder of the implementation of the federal system is important. The IPC convened its inaugural meeting in December 2018, which provided a platform for the Prime Minister and Chief Ministers to discuss immediate challenges affecting implementation of federalism. The meeting resulted in the formation of a task force to propose measures for addressing federalism implementation issues raised by the chief ministers. However, the IPC doesn't meet regularly to discuss federalism implementation challenges. Nearly four years after the constitution went into effect, the IPC had met only three times. ${ }^{12}$

The National Natural Resources and Fiscal Commission (NNRFC) is charged in the Constitution with recommending/determining the distribution of revenues to provincial and local governments from the consolidated fund. There has been considerable delay in empowering this Commission. In March 2019, the President appointed a chair of the NNRFC Commission, but the full membership of this independent commission had not been nominated at the time of this writing. The Constitution also establishes a Secretariat to carry our research, monitoring and policy

\footnotetext{
${ }^{11}$ Even after been established, provincial public service commissions could not start recruiting provincial and local staff until employee duties and benefits were established in the two respective federal framework laws: Provincial Civil Service Act and the Local Service Act. But before these bills could be introduced, the Federal Civil Service Act had to be passed.

${ }^{12}$ At its second meeting, the Council laid out a "federalism implementation Action Plan," which identified 29 actions that the federal government needed to take to allow a smooth transition to the federal governance structure.
} 
analysis for the Commission. In fact, a secretariat to the Commission is functioning and has established an interim system of intergovernmental transfers. At present, however, the NNRFC secretariat is an arm of the federal government.

The NNRFC may turn out to be a controversial body in contributing to policy as regards Nepal's fiscal federalism. Fiscal commissions in federal countries are not uncommon and are usually charged with making recommendations to government about changes in the system of intergovernmental finance. However, in the case of Nepal, the wording in the Constitution directs that the vertical shares of intergovernmental transfers and the horizontal distributions "shall be as recommended by the NNRFC" $($ Art. $60,(3,4))$. This is a step further than other countries have gone on the powers given to fiscal commissions, and could increase the role played by the political economy in structuring intergovernmental transfers (Yilmaz and Zahir, 2020).

\section{Capacity Building and Training}

The expected staff level, including service delivery employees, in the seven provincial governments is about 21,000 , and that in the 753 local governments is about 66,000 . In addition, there are about 37,000 newly elected local government officers, and 550 elected provincial government officers. Retooling employees and management in Nepal and educating lawmakers about their new duties will be no small job.

Until the Fiscal Capacity Needs Assessment (FCNA) study, there had been no survey of public sector training needs in Nepal. That is to say, there had been no plan that laid out the detail of the kind of training and capacity building that is necessary for government officials in the federal system. Nor was there an estimate of how much it might cost to put such a capacity development system or an institutional arrangement in place to accommodate the level of training needed. In 
August 2019, the Government of Nepal launched the Provincial and Local Governance Support Programme (PLGSP) as the main vehicle for capacity building to strengthen provincial and local government systems, procedures and intergovernmental relations with the total amount of government and donor funding pledged at US\$130 million. PLGSP is a framework program for the development partners choosing to align their efforts and commit to joint funding and joint decision making. Furthermore, PLGSP adopted the FCNA findings as the baseline to plan its interventions. However, PLGSP envisions its capacity building activities to be demand driven with provincial and local governments identifying their specific needs and requesting capacity building from the menu of options offered by PLGSP.

\section{Public Financial Management (PFM)}

The Government of Nepal is continuing the important process of developing a financial management system aimed at modernizing practices related to budget formulation and control, and financial practices and reporting. The extension of PFM practices to sub-national governments is a high priority.

Provincial and local governments in Nepal do not have easy access to financial information in a form necessary to plan and manage their budgets in an efficient way, yet expectations for their performance in this area are high. The Constitution and subsequent legislation call on subnational governments to make estimates of expected revenues and expenditures at the beginning of each fiscal year, to carry out medium-term expenditure forecasts, and to obey a hard budget constraint.

The present state of public financial management practices by sub-national governments in Nepal may be four to five years away from being one that provides reasonable fiduciary guarantees and supports an acceptable level of service delivery. Procurement capacity is 
particularly weak. But there has been progress in the first two years of the new federalism, e.g., most local governments have a consolidated account, voted on a budget on time, executed the FY 2018 budget, and had their accounts audited. Projects underway since 2011 have led to successful implementation of the treasury single account, more transparent expenditure reporting, a revenue management information system, and an upgraded audit methodology. The next round of work on PFM in Nepal will have more emphasis on sub-national governments, and a goal of integrating budgeting processes across all levels of government.

\section{Gender Equality and Social Inclusion (GESI)}

Nepal is one of the poorest countries in South Asia and discrimination against disadvantaged populations is deep seated. The Human development Index (HDI) index ranks it 149 of 189 countries, and the gender inequality index ranks 118 of 189 (UNDP, 2018). The adult literacy rate is 71 percent for males and 45 percent for females. For every 100 males in the working-age population there are 125 females. Yet, for every 100 employed males there are only 59 employed females. Gender disparities also exist among the unemployed, and women earn on average 70 percent of what men earn. World Bank Group (2019, p. 43). The new Constitution guarantees equal opportunity rights to challenge such inequities. There has been considerable progress.

In the 2017 elections, 38 percent of Assembly seats were won by women and 21 percent by other disadvantaged groups. The Government of Nepal adopted "mainstreaming" gender equality and social inclusion by including it in all decisions about governance and government operations. In the 2017/2018 budget speech, about 36 percent of the total federal budget was classified as "gender responsive" and about 30 percent was classified as "gender neutral."

Much remains to be done to continue to move the GESI agenda forward. Elected representation is important but, as the federal government has noted, the absence of formal channels of 
participation in government decisions by the disadvantaged is the missing link for ensuring inclusive local governance. Gender budgets are in place, but more concrete evidence is required to conclude that gender-based budgets in Nepal have been effective.

With respect to the implementation of federalism, two factors are in play that have the potential to influence gender balance. First, the provincial public service commissions could provide a new opportunity to rethink gender balance in hiring practices at the sub-national government level. Second, time and public policies might help soften some barriers to more participation by women and minorities, e.g., it takes time for newly elected representatives to gain enough power to make a difference in governance, and an increased literacy rate can improve the competitiveness of women for better postings. Moreover, the social constraints that women face - child rearing, domestic chores, etc. - might be relaxed by the better proximity to the workplace that could come with the establishment of full-fledged local governments.

\section{Fiscal Capacity}

Provincial and local governments in Nepal are heavily dependent on intergovernmental transfers to finance their budgets. The Constitution makes room for locally raised revenues, and even borrowing, but outside the larger urban areas, neither of these are likely to soon become major sources of revenue. ${ }^{13}$

National revenue mobilization has been buoyant, and GDP has been rising, so the level of intergovernmental transfers in the first two years of federalism has risen to meet sub-national government needs. But an increased claim on federal revenues, attributable directly or indirectly

\footnotetext{
${ }^{13}$ In most municipalities, own-source revenue accounted for less than 10 percent of their budgets in the first fiscal year after the local elections (2017-18). However, in some metropolitan municipalities, own sources accounted for between 40-50 percent of their budgets (e.g., 51 percent in Kathmandu).
} 
to the transition to federalism, could come in the next few years. The costs of managing provincial and local governments and of delivering services will increase as the full complement of provincial and local government employees comes into place, training and capacity building will absorb significant revenues, the demands for better services at the local level will rise as voters' expectations rise, and the infrastructure deficit will need to be addressed.

The federal government and the Parliament, in consultation with the NNRFC Secretariat, has kept the intergovernmental grant system on track in its first two years. However, as federalism is more fully implemented, the system will need to be revisited to examine its impacts, consider reform options, and assess the increased claim on federal government revenues. The key agency in this work will be the NNRFC. Because the Constitution states that the recommendations of the NNRFC on grant levels and distributions are binding, a high priority will be to develop cooperative arrangements with Parliament, the federal government, and the Interprovincial council, among others. Possibly due to the lack of full membership, until now NNFRC could not interact with the Parliament directly but had to channel all submissions through the Ministry of Finance.

\section{Capacity Needs Assessment for Provincial and Local Governments}

The Government of Nepal commissioned The Fiscal Capacity Needs Assessment (FCNA) project, sponsored by the World Bank and UNDP(GSU, 2019), to carry out field work to better understand the current state of operations and finances and to get a general sense of the capacities of sub-national governments to manage and deliver local public services. The capacity of all seven provincial governments was assessed through structured interviews carried out by international and local members of the study team. By contrast, for the local governments, the 
300-question survey was administered to all 17 cities and a stratified random sample of 98 other municipalities.

While there are important variations in the findings, the survey results identify a number of capacity gaps that appear to be widespread. Provincial and local governments generally have the basic capacity to "keep the lights on." This is commendable given that some of those government units were created from scratch within the past two years. However, when it comes to the quality of local management, a number of critical elements are missing in many, if not a majority, of jurisdictions. Five such areas emerge in the survey: 1) medium-term planning; 2) clear roles and responsibilities of individual staff; 3) procurement; 4) managing performance of organizational units and individuals; and 5) GESI.

Physical Infrastructure. More than one half of municipalities and rural municipalities rented at least some of their buildings. About 70 percent of cities felt that their building could accommodate an assembly meeting, but only 39 percent of urban municipalities and 61 percent of rural municipalities felt this to be the case.

On the other hand, most provincial governments were using rent-free buildings owned by other levels of government. Practically all provinces felt that their buildings could not accommodate an assembly meeting, and many would have had difficulties accommodating a cabinet meeting. For provincial staff, their present office space seemed adequate, but this advantage will dissipate as they become fully staffed.

There also were significant variations among local governments in terms of essential support services and office amenities. All cities were connected to the national power grid and had significant generator backup, but 11 percent of urban municipalities and 28 percent of rural 
municipalities, especially those in the mountainous ecological zone, were not connected to the national power grid. Cities, as well as most other local governments outside the mountainous ecological zone, were connected to the internet and had computers and printers in quantities adequate for the present staff counts. Provincial governments had better access to office amenities, public utilities and the internet, though there was some variation across the provinces.

All cities had reliable landline and cell service, but only about half of rural municipalities had landline telephone services that they found reliable. However, other municipalities depended more heavily on cell phones, which were commonly reported as unreliable in the mountainous ecological zone.

The situation in provincial governments is better, with all having internet connections and a sufficient number of computers. However, this will change as vacant positions become filled. No data management systems were available except those used for budget and accounting purposes.

Human Resources Management. Seconded staff filled fewer than one half of positions in local government offices. More positions were filled with contractual staff and those carried over from the local government bodies that previously existed. However, the latter tended to be either general public administration or support staff. As a result, many high-skill technical positions, such as engineers, lawyers, and accountants, remained vacant. There was a particularly high vacancy rate for engineers: almost one half nationwide and over two thirds in sub-metropolitan cities. Surprisingly, vacancy rates increased with the level of urbanization.

About one half of local governments had written job descriptions available for all positions envisioned in their organizational structure, and only about 15 percent of non-metropolitan local cities did not have written job descriptions available for any positions. Less than one third of 
local governments reported having their own laws/policies for managing their staff, in terms of leave approval, performance appraisal, reporting rules, etc. More than two thirds of local governments followed staff performance review mechanisms compared to less than one fifth that never did. However, over 40 percent of municipalities and rural municipalities never practiced sanctions for under-performance.

While the organizational structures were more or less uniform across provincial administrations, there were differences in vacancy rates, ranging from one quarter of approved positions to one half across provinces. This added up to about 1,000 vacant positions in public administration (excluding service centers such as veterinarian clinics). On average, 15 percent of existing provincial government staff were contractual, used primarily for support roles such as office assistants and drivers, but a few are more skilled employees, such as computer operators.

\section{Lessons for the Practice}

Nepal's decentralization was driven by the need for cohesion while the country recovered from an internal conflict. The strategy is to convert Nepal from a highly centralized unitary country to a democratic, cooperative federalism with three tiers of government, to give significant budgetary and operation autonomy tor the subnational governments, and to make strong provisions for more equality of opportunity. The general vision was more or less clear, and raised the expectations of the population for improved public services and more citizen participation in governance.

The Nepal case may offer some useful lessons for implementing a comprehensive public sector reform, including a strategy for covering the cost of the reform, tempering expectations about how long it would take to implement the full reform, identifying the proper sequencing of 
introducing the necessary reforms, and making necessary ongoing adjustments to the implementation plans. Five components of such a strategy might be identified.

First and most important, a full implementation plan should have been prepared by a blue-ribbon commission of experts, drawn from all stakeholder representatives. The plan should be updated periodically, and should be made available as a public document. This would have allowed the government sector to set a timeline for the rollout of the full reform and in so doing, it would cool the high expectations that the public had for a quick fix. It also would have steered the government toward focusing on the correct sequencing of reforms rather than to cherry pick those deemed most feasible (Bahl and Martinez-Vazquez, 2006). In the case of Nepal, however, even the full implementation plan and calendar was not yet in place by 2020, nearly five years into the process.

Second, the constitution provided for the appointment of an independent NNRFC to design the distribution of intergovernmental transfers, and to monitor the distribution of transfers. Instead, a Secretariat for this commission was appointed by the federal government and has carried out the analysis that provides for these objectives. This is not what the Constitution had envisioned. As of 2019, the independent Fiscal Commission had not yet been fully appointed. If, upon its appointment the Commission decides on a major change in the distribution of transfers, and if the binding feature of its recommendations becomes reality, a significant transactions cost might be involved, and the NNRFC could lose some creditability in the process. In fact, the appointment of all institutions that were provided in the new Constitution should have occurred shortly after ratification of the constitution.

Third, a capacity development plan, including institutional arrangements and financing should have been an early priority. At the time of the enactment of the Constitution in 2015, it was clear 
(or could easily have been made clearer), that the human resource capacity (both numbers of employees at each level of government, and the mix of qualifications needed), were inadequate to meet the expenditure assignment responsibilities laid out in the new Constitution. As of 2020, a plan for training has not yet been completed, though it seems clear that the cost of the task will be well beyond the short run budget resources of the GON.

Fourth, the full legal framework to operate the new federal system is still not in place. An initial task could have been to identify all necessary legislation and regulations, for all three levels of government. Implementation could have been fast-tracked and prioritized. In fact, even by 2019, enabling legislation was holding up operationalization of provincial civil service commissions. This slowed down the decentralization and held up the progress.

Fifth, the data and other information needed to monitor the economic development, expenditure needs and fiscal performance could have gone forward independently. A data system and analytic cell should have been institutionalized and used for regular evaluation of the intergovernmental fiscal system as early as the first year of implementation. Other than the work of the secretariat of the Fiscal Commission, this kind of monitoring and database development is still not in place.

Finally, the Nepal case is a good illustration of what can happen in the absence of a strong champion for fiscal decentralization. A "champion" could have been a person or institution who would have continuously moved the needle in the directions that the Constitution defined. Since the main beneficiaries of federalization are the people, one might expect the champions to be heads of state, leaders in Parliament and strong mayors or governors. But central government bureaucrats are usually not good champions because they may lose power and the right of "parental discretion" with a move toward decentralization. Even subnational government 
officials might push for power before they have the capacity to deliver services and could disillusion voters about the virtues of decentralized service delivery. All of these factors have contributed to the slow (and costly) development of a full implementation of fiscal federalism in Nepal. 


\section{References}

Bahl, R. and Martinez-Vazquez, J. (2006a). Sequencing fiscal decentralization. Policy research paper 3914. Washington DC: World Bank.

Bahl, R. and Bird, R. (2018). Fiscal decentralization and local finance in developing countries: Development from below. Cheltenham, UK; Northampton MA, USA: Edward Elgar Publishing, Edward Elgar.

Collier P. 1994. Demobilization and Insecurity: A Study in the Economics of the Transition from War to Peace. Journal of International Development, 1994(3).

Constitution of Nepal, 2015.

Democracy Resource Center. (2017, November). Nepal's local elections, 2017: Final observation report. Kathmandu.

Democracy Resource Center. (2018, August) Findings on Functioning of Local and Provincial Governments in Nepal: Final report. Kathmandu.

Georgia State University [GSU] (2019, July). Nepal: Capacity Needs Assessment for The Transition to Federalism. Unpublished report commissioned by the World Bank and the United Nations Development Programme (UNDP).

Kelly, Roy. (2016). "Stocktaking of Fiscal Decentralization Policy in Nepal”, Journal of Fiscal Federalism, July 2016, pp. 1-16. ISSN 2542-2626

Nepal Administrative Staff College [NASC]. (2018). Nepal National Governance Survey 2017/18. Lalitpur: Nepal Administrative Staff College.

Pokharel, Champak P. (2009) "Assessment of Expenditure Decentralization on the Road towards Federalism in Nepal," Appendix II in Musharraf R. Cyan, Nepal's Choices in Fiscal Federalism, Nepal Resident Mission, Asian Development Bank.

Ra, Sungsup and Bipul Singh (2005). Measuring the economic costs of conflict: the effect of declining development expenditures on Nepal's economic growth, Asian Development Bank Working Paper Series No. 2, Nepal Resident Mission

Wodon, Q., and B. de la Brière. 2018, Unrealized Potential: The High Cost of Gender Inequality in Earnings. The Cost of Gender Inequality Notes Series. Washington, DC: The World Bank. Available at https://openknowledge.worldbank.org/handle/10986/29865 (accessed on $02 / 15 / 2020)$.

World Bank Group (2019). Investing in People to Close the Human Capital Gap , Nepal Development Update (Kathmandu, May).

Yilmaz, Serdar and Farah Zahir (2020). "Issues in Intergovernmental Fiscal transfers: Public Finance and Political Economy Considerations" Intergovernmental Transfers in Federations, edited by Serdar Yilmaz and Farah Zahir (Cheltenham, UK; Northampton MA, USA: Edward Elgar Publishing, pp21-40. 